\begin{tabular}{|c|c|c|c|}
\hline \multirow{3}{*}{$\begin{array}{r}\text { Case Reports in } \\
\text { Gastroenterology }\end{array}$} & \multirow{2}{*}{\multicolumn{2}{|c|}{ Case Rep Gastroenterol 2019;13:253-257 }} & \multirow[b]{3}{*}{$\begin{array}{l}\text { Karger } \\
\text { Open'access }\end{array}$} \\
\hline & & & \\
\hline & $\begin{array}{l}\text { DOI: 10.1159/000500078 } \\
\text { Published online: June 13, } 2019\end{array}$ & $\begin{array}{l}\text { (c) } 2019 \text { The Author(s) } \\
\text { Published by S. Karger AG, Basel } \\
\text { www.karger.com/crg }\end{array}$ & \\
\hline & $\begin{array}{l}\text { This article is licensed under t } \\
\text { International License (CC BY-NC } \\
\text { Usage and distribution for comm }\end{array}$ & $\begin{array}{l}\text { mons Attribution-NonCommercial } 4.0 \\
\text { rger.com/Services/OpenAccessLicense). } \\
\text { quires written permission. }\end{array}$ & \\
\hline
\end{tabular}

\title{
Challenges Associated with Colorectal Cancer in Pregnancy
}

\author{
J.M.V. Amarjothi Villalan Ramasamy G.R. Senthil Kumaran \\ O.L. Naganath Babu \\ Department of Surgical Gastroenterology, Madras Medical College, Chennai, India
}

\section{Keywords}

Colorectal cancer · Adenocarcinoma · Pregnancy

\begin{abstract}
Colorectal cancer is epidemiologically a disease of the middle-aged and elderly. However, it may occur in the young where it presents with virulent biological behavior and poor prognosis. The symptoms of colorectal cancer may be masked by symptoms of pregnancy and the patient may attribute it to the pregnancy, especially in multiparous patients whose anxiety and apprehension levels may be lower and hence present late to health care providers. Antenatal women who present with such symptoms must be investigated further under the available repertoire of investigations possible in pregnancy without causing any maternal or fetal hazard. Treatment with chemotherapy and radiation for cancer in this setting is further hampered by justifiable concerns over fetal well-being. We present a case of colorectal cancer in a young multiparous female and the associated difficulties in diagnosis and management. The challenges with colorectal cancers and pregnancies are expected to rise in the future with a decreasing trend in age of colorectal cancer occurrence and an increasing age of pregnancy due to lifestyle changes.

(c) 2019 The Author(s)

Published by S. Karger AG, Basel
\end{abstract}

\section{KARGER}

Amarjothi J.M.V.

Department of Surgical Gastroenterology

Madras Medical College

Room 500, 4th floor, Tower 2, EVR Salai, Chennai, Tamil Nadu 600003 (India)

E-Mail drmosesvikramamarjothi@hotmail.com 


\section{Introduction}

Pregnant women and health care providers may not think of non-obstetric causes, especially colorectal cancer for common symptoms of pregnancy like constipation, till it may become advanced [1]. Colorectal cancer can occur in the young during pregnancy even without a family history. Patients may mistake symptoms of colorectal cancer like nausea, abnormal bowel movement, and per rectal bleeding for symptoms of pregnancy, which may lead to a delay in the diagnosis and treatment. These tumors in the young are usually with poor differentiation and higher metastatic potential resulting in poor prognosis [2]. A higher index of suspicion must exist for non-obstetric causes of intestinal obstruction, especially in those with persistent obstruction. A low threshold for investigations is in order to diagnose those with atypical or persistent symptoms. This report stresses the need for a wide range of differentials including malignancy in pregnancy, though it is uncommon.

\section{Case Report}

A 24-year-old female pregnant with third child (G3P2L2) presented with persistent features of intestinal obstruction, even 2 days after child birth by cesarean section for fetal distress at the end of 36 weeks of gestation. The patient had features of decreased frequency of passing stools, abdominal bloating and tenesmus for the past 2 months of pregnancy which she attributed to the advanced state of her pregnancy. There were occasional episodes of bleeding per rectum for the last month, which the patient thought were due to anal fissure, a condition she had during her previous pregnancy. She had gained about $9 \mathrm{~kg}$ of weight since her pregnancy (58-67 kg), but there was a loss of appetite for the past few months, which was attributed by her to the pregnancy. There was no history of melena, jaundice or hematemesis.

There were 2 previous live births and no previous history of abortion. There was no history of familial cancer. Previous antenatal ultrasound done at 3 and 6 months of gestation revealed a well-formed fetus with no abnormalities. She did not present for further visits thereafter till the time of delivery. On examination, the patient was tachycardic and the abdomen was distended. Per rectal examination revealed an ulcer proliferative growth in the lower rectum about $5 \mathrm{~cm}$ from the verge almost occluding the lumen.

$\mathrm{X}$-ray showed multiple dilated bowel loops involving the small and large bowel with no evidence of perforation. As a closed-loop obstruction was thought likely, emergency diverting sigmoid loop colostomy was done. Later, CECT of the abdomen (Fig. 1) was done which showed circumferential growth involving the middle and distal rectum with right hydroureteronephrosis due to prior extrinsic compression of the right ureter by the gravid uterus. Colonoscopy (Fig. 2) showed a lesion of $6 \mathrm{~cm}$ from the verge. The scope could not be passed beyond. CEA was $1.9 \mathrm{ng} \%(N<5 \mathrm{ng} \%)$. Colonoscopic biopsy was negative on two successive occasions and the third biopsy was positive for poorly differentiated adenocarcinoma with signet ring features.

The patient was started on FOLFOX chemotherapy, but she developed lung and peritoneal metastasis after 4 months. She refrained from further investigations and died 6 months after colostomy due to disseminated disease. 


\section{Discussion}

Cruveilhier [3] reported the first case of rectal carcinoma in pregnancy in 1842. Colorectal cancer is the seventh most common type of cancer diagnosed in pregnancy, with an estimated incidence of 1 in 13,000 pregnancies [4]. The mean age of diagnosis in a large review was 31 years [2].

The carcinogenesis of colorectal cancer in pregnancy is not fully understood but increased estrogen receptors and progesterone receptors may be involved in the pathogenesis [5]. Cox-2 enzymes are found to be vital to normal pregnancy and high levels are seen in many colorectal tumor cells. This has prompted the inference that Cox-2 inhibitors such as aspirin can alter the course of colon cancer [6].

There are many challenging issues regarding the diagnosis and management of colorectal cancer in pregnancy as it can be masked by the signs and the symptoms of the pregnancy [1]. Abdominal bloating, loss of weight due to malignancy-induced cachexia, and loss of appetite are likely to be masked by pregnancy. Abdominal pain secondary to the partial large-bowel obstruction may be considered as normal uterine cramps. Anorectal bleeding and perianal pain may be misdiagnosed as engorged hemorrhoid and anal fissure, respectively, conditions common in pregnancy [7]. Especially in multiparous women like our patient, occasional rectal bleeding and crampy abdominal pain are more likely to be misdiagnosed as normal course of pregnancy for a few weeks as the trepidation and anxiety for any new symptoms seen in a primigravida is usually not present. Most cases of colorectal cancer are diagnosed late in pregnancy when widespread metastases have occurred [4]. 86\% of colorectal tumors found in the rectum during pregnancy occur below the peritoneal reflection in the lower rectum [8]. Hence, this necessitates at least a simple per rectal examination in suspicious cases. Most (60\%) are advanced, stage III, and present in the second and third trimester with poor outcomes $[8,9]$.

The role of diagnostic investigations in colorectal cancer like contrast-enhanced computed tomography is limited as it may compromise fetal well-being [10, 11]. Ultrasound, though a safe diagnostic modality in pregnancy, has poor accuracy in detecting colon and rectal cancer. Magnetic resonance imaging is relatively safe in pregnancy, but the role of safety of its contrast agents and its availability is a cause for concern [11-13].

A gentle flexible rectosigmoidoscopy may be preferred in a suspicion of rectosigmoid cancer in pregnant women, especially in the second trimester. Investigations like completion colonoscopy and endoscopic ultrasound are done in confirmed cases. Carcinoembryonic antigen and liver ultrasound may be needed for those with high pretest probabilities of advanced disease [2].

Treatment of colorectal cancer in pregnancy is challenging and should be started as early as possible keeping in mind the welfare of both mother and child. Generally, in the first 20 weeks of pregnancy, pregnancy may need to be terminated and early cancer treatment should be started as treatment delay can lead to disease progression and maternal mortality. After 20 weeks of pregnancy, the treatment is less well defined. Surgery may be delayed till the fetus is viable and then therapy may be started after consultation [14]. It has been proposed that colon cancer surgery can be done right after an uncomplicated cesarean section [8]. The mode of delivery is generally not affected by cancer, though the placenta should be carefully examined for metastases [15].

Chemotherapy, though safer during the second and third trimester of pregnancy than the first trimester, is associated with an increase in the incidence of intrauterine growth retardation and prematurity as brain development is not yet complete [16]. 
As most of these rectal cancers are at least stage III necessitating chemoradiation, pelvic radiation and chemotherapy can theoretically compromise the fetus. Most evidence indicates that neoadjuvant chemotherapy in pregnant women with metastatic rectal cancer may spare the fetus though affecting maternal cure rates [10].

\section{Conclusion}

Challenges of both diagnosis and treatment in colorectal cancer are further compounded by pregnancy. Hence, accurate diagnosis and prompt treatment is the cornerstone in effective management.

\section{Statement of Ethics}

The authors declare no ethical conflict. No ethical approval was required for this case report. The authors state that subjects have given their informed consent and that the study protocol has been approved by the institute's committee on human research. Consent of the next of kin was obtained prior to preparation of the manuscript.

\section{Disclosure Statement}

The authors declare no conflicts of interest. The authors have no financial disclosure.

\section{Author Contributions}

Amarjothi J.M.V.: conceptualization; data curation; formal analysis.

Villalan R., Senthil Kumaran G.R.: investigation; supervision; validation; visualization; roles/writing - original draft; writing - review and editing.

Naganath Babu: roles/writing - original draft; writing - review and editing.

\section{References}

1 Morice P, Uzan C, Uzan S. Cancer in pregnancy: a challenging conflict of interest. Lancet. 2012 Feb;379(9815):495-6.

2 Yaghoobi M, Koren G, Nulman I. Challenges to diagnosing colorectal cancer during pregnancy. Can Fam Physician. 2009 Sep;55(9):881-5.

3 Cruveilhier JJ. Anatomie pathologique du corps humaine. Volume 2. Paris, France: JB Baillière; 1829. pp. 710.

4 Woods JB, Martin JN Jr, Ingram FH, Odom CD, Scott-Conner CE, Rhodes RS. Pregnancy complicated by carcinoma of the colon above the rectum. Am J Perinatol. 1992 Mar;9(2):102-10.

5 Korenaga D, Orita H, Maekawa S, Itasaka H, Ikeda T, Sugimachi K. Relationship between hormone receptor levels and cell-kinetics in human colorectal cancer. Hepatogastroenterology. 1997 Jan-Feb;44(13):78-83.

6 Giovannucci E, Rimm EB, Stampfer MJ, Colditz GA, Ascherio A, Willett WC. Aspirin use and the risk for colorectal cancer and adenoma in male health professionals. Ann Intern Med. 1994 Aug;121(4):241-6.

7 Khodaverdi S, Kord Valeshabad A, Khodaverdi M. A case of colorectal cancer during pregnancy: a brief review of the literature. Case Rep Obstet Gynecol. 2013;2013:626393.

8 Bernstein MA, Madoff RD, Caushaj PF. Colon and rectal cancer in pregnancy. Dis Colon Rectum. 1993 Feb;36(2):172-8. 
Amarjothi et al.: Colorectal Cancer in Pregnancy

9 Dogan NU, Tastekin D, Kerimoglu OS, Pekin A, Celik C. Rectal cancer in pregnancy: a case report and review of the literature. J Gastrointest Cancer. 2013 Sep;44(3):354-6.

10 Peccatori FA, Azim HA Jr, Orecchia R, Hoekstra HJ, Pavlidis N, Kesic V, et al.; ESMO Guidelines Working Group. Cancer, pregnancy and fertility: ESMO Clinical Practice Guidelines for diagnosis, treatment and follow-up. Ann Oncol. 2013 Oct;24 Suppl 6:vi160-70.

11 Baysinger CL. Imaging during pregnancy. Anesth Analg. 2010 Mar;110(3):863-7.

12 Chen MM, Coakley FV, Kaimal A, Laros RK Jr. Guidelines for computed tomography and magnetic resonance imaging use during pregnancy and lactation. Obstet Gynecol. 2008 Aug;112(2 Pt 1):333-40.

13 Hodnett PA, Maher MM. Imaging of gastrointestinal and hepatic diseases during pregnancy. Best Pract Res Clin Gastroenterol. 2007;21(5):901-17.

14 Walsh C, Fazio VW. Cancer of the colon, rectum, and anus during pregnancy. The surgeon's perspective. Gastroenterol Clin North Am. 1998 Mar;27(1):257-67.

15 Dildy GA 3rd, Moise KJ Jr, Carpenter RJ Jr, Klima T. Maternal malignancy metastatic to the products of conception: a review. Obstet Gynecol Surv. 1989 Jul;44(7):535-40.

16 Sommers GM, Kao MS. Using chemotherapeutic agents during pregnancy. Contemp Obstet Gynecol. 1987;30:45-8.
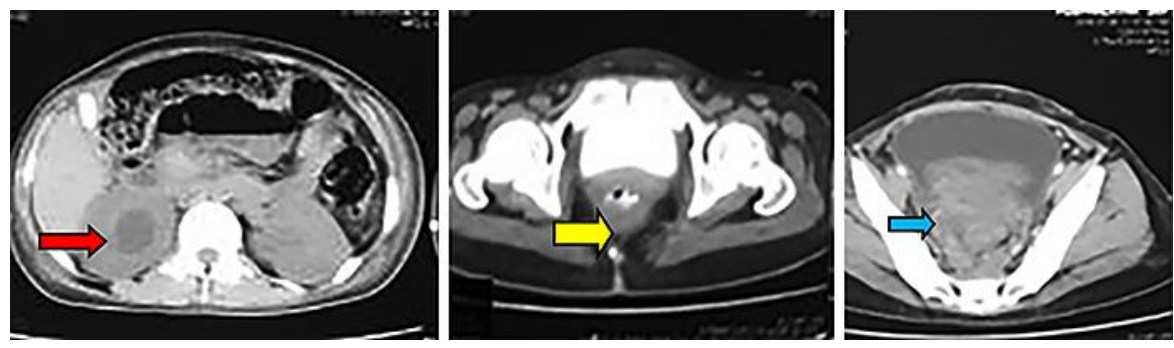

Fig. 1. CECT showing an involuting uterus (blue arrow) and circumferential stenosing lesion in the rectum (yellow arrow) and right hydroureteronephrosis (red arrow) due to compression by the gravid uterus.

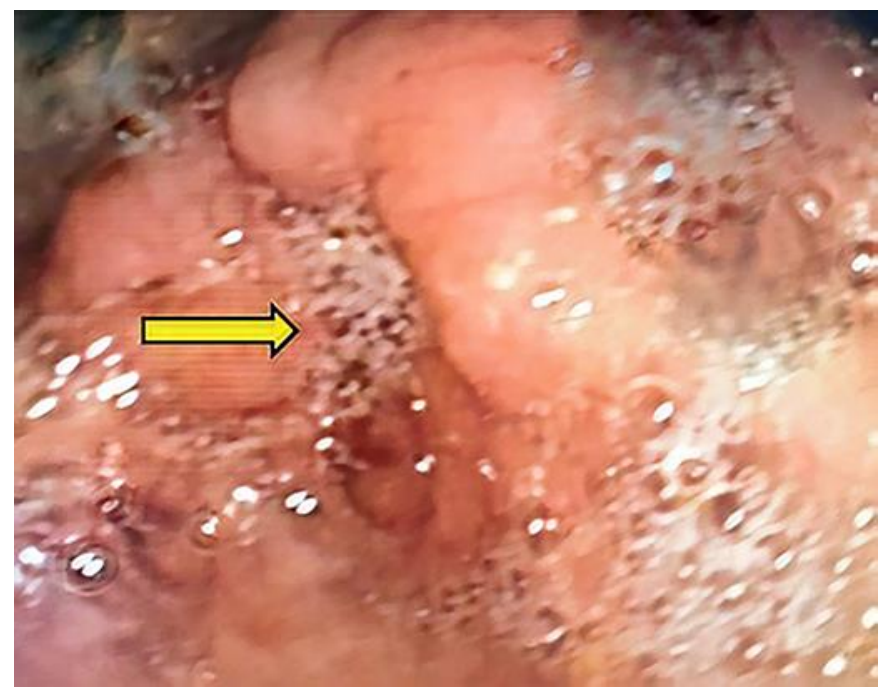

Fig. 2. Colonoscopic picture showing completely stenosing lesion in the rectum with absence of lumen (yellow arrow). 